\title{
A Case of Primary Biliary Cirrhosis Associated with Hashimoto's Thyroiditis, Scleroderma and Sjögren's Syndrome
}

\author{
Masakazu Horita, Naohiko Takahashi, Masataka Seike, Shinji Nasu and Ryosaburo Takaki
}

\begin{abstract}
A 53-year-old woman was admitted because of Raynaud's phenomenon, polyarthralgia and polymyalgia. Biopsy specimens of the liver and thyroid gland revealed characteristic findings of primary biliary cirrhosis (PBC) (stage I by Scheuer's classification) and chronic thyroiditis. Her clinical features were also complicated by scleroderma (type I by Barnett's classification) and Sjögren's syndrome (Sjs) with keratoconjunctivitis sicca. Thyroid hormone replacement therapy led to improvement in thyroid function, normalization of the biliary tract enzymes and alleviation of subjective symptoms.
\end{abstract}

(Internal Medicine 32: 418-421, 1992)

Key words: autoimmune disease, thyroid hormone replacement therapy, antimitochondrial antibody, anticentromere antibody

\section{Introduction}

Primary biliary cirrhosis (PBC) is an autoimmune disease with a poor prognosis that occurs most frequently in middle-aged women. It is characterized serologically by a positive antimitochondrial antibody test and histologically by chronic non-suppurative destructive cholangitis (CNSDC). Furthermore, $\mathrm{PBC}$ is known to be associated with other autoimmune diseases (1). We observed a patient diagnosed as having asymptomatic PBC complicated by Hashimoto's thyroiditis, scleroderma and Sjögren's syndrome (Sjs). To the best of our knowledge, there has been only one other report of a similar case in Japan (2). It is noteworthy that thyroid hormone replacement therapy led to improvement in thyroid function, normalization of biliary tract enzymes and alleviation of subjective symptoms.

\section{Case Report}

A 53-year-old woman suffered from Raynaud's phenomenon for the past twenty years. In 1987, she was diagnosed by a local physician as having Hashimoto's thyroiditis. Systemic arthralgia with dorsal and hypochondrial myalgia appeared in May of 1988, and she was admitted to our hospital on November 29 of that year. Two months prior to her admission, she experienced a sensation of dryness of the mouth. Her elder sister has Grave's disease. Her younger sister died of renal failure that developed as the result of an unknown type of collagen disease.

On admission, the patient's height was $156 \mathrm{~cm}$ and her body weight was $55 \mathrm{~kg}$. Her temperature was $36^{\circ} \mathrm{C}$, pulse rate was $78 / \mathrm{min}$ and blood pressure was $136 / 88 \mathrm{mmHg}$. Physical examination failed to demonstrate jaundice of the tunica conjunctiva bulbi. Cervical palpation revealed a diffuse, elastic goiter. Respiratory sounds were clear and heart sounds were normal. The liver and spleen were not palpable. Her extremities showed Raynaud's phenomenon and sclerodactylia in the fingers (Fig. 1), but there were no abnormal neurogical findings.

Laboratory findings (Tables 1,2 ) were as follows. Blood cell counts were normal. With respect to blood chemistry, elevations in $\gamma$-globulin $(27.5 \%)$, GOT $(58 \mathrm{IU} / 1), \mathrm{LDH}(454 \mathrm{IU} / \mathrm{l})$ and biliary tract enzymes (ALP: 335 IU/1, LAP: 110IU/1, $\gamma$-GTP: $62 \mathrm{IU} / 1$ ) were found. However, the aldolase level was within normal limits. Serological examination revealed the presence of antinuclear antibodies $(\times 640)$, antithyroglobulin antibody $(\times 1,600)$, antimicrosomal antibody $(\times 1,600)$, antimitochondrial antibody $(\times 160)$, anti-smooth muscle antibody $(\times 320)$ and anticentromere antibody $(\times 640)$. In addition, immune complexes were detected $(4.5 \mathrm{mg} / \mathrm{dl})$ and $\operatorname{IgG}$ was elevated $(2,300 \mathrm{mg} / \mathrm{dl})$, but IgM was normal

From the First Department of Internal Medicine, Medical College of Oita, Oita

Received for publication March 6, 1991; Accepted for publication September 25, 1991

Reprint requests should be addressed to Masakazu Horita, M.D., the First Department of Internal Medicine, Medical College of Oita, 1-1 Idaigaoka, Hazama-cho, Oita-gun, Oita 879-55, Japan 
PBC, Thyroiditis, Scleroderma, and Sjs

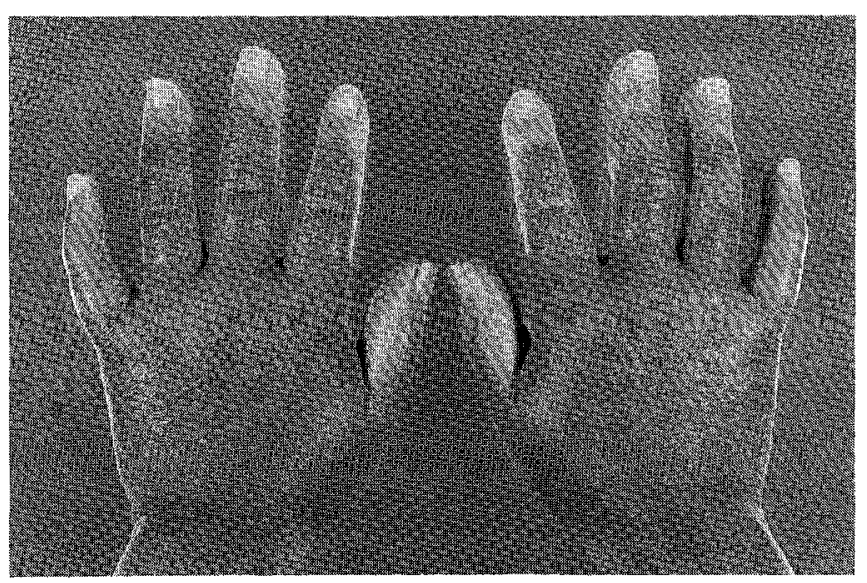

Fig. 1. Sclerodactylia with Raynaud's phenomenon

Table 1. Laboratory Findings on Admission (1)

\begin{tabular}{|c|c|c|c|}
\hline \multirow{6}{*}{$\begin{array}{l}\text { Urine } \\
\text { glucose } \\
\text { protein } \\
\text { bilirubin } \\
\text { urobilinogen }\end{array}$} & \multicolumn{3}{|c|}{ Blood chemistry } \\
\hline & $(-)$ & $\mathrm{TP}$ & $7.9 \mathrm{~g} / \mathrm{dl}$ \\
\hline & $(-)$ & $\mathrm{Alb}$ & $58.8 \%$ \\
\hline & $(-)$ & $\gamma-\mathrm{gl}$ & $27.5 \%$ \\
\hline & $( \pm)$ & TBil & $0.6 \mathrm{mg} / \mathrm{dl}$ \\
\hline & & TTT & $28 \mathrm{KU}$ \\
\hline \multicolumn{2}{|l|}{ Peripheral blood } & GOT & $58 \mathrm{IU} / \mathrm{l}$ \\
\hline $\mathrm{RBC}$ & $404 \times 10^{4} / \mathrm{mm}^{3}$ & GPT & $30 \mathrm{IU} / \mathrm{I}$ \\
\hline $\mathrm{Hb}$ & $12.1 \mathrm{~g} / \mathrm{dl}$ & $\mathrm{ChE}$ & $7.0 \times 10^{3} \mathrm{IU} / \mathrm{l}$ \\
\hline Ht & $36.4 \%$ & ALP & $335 \mathrm{IU} / 1$ \\
\hline Plat & $13.2 \times 10^{4} / \mathrm{mm}^{3}$ & LAP & $110 \mathrm{IU} / \mathrm{l}$ \\
\hline WBC & $4,940 / \mathrm{mm}^{3}$ & $\gamma-\mathrm{GTP}$ & $62 \mathrm{IU} / \mathrm{l}$ \\
\hline EOSI & $5.8 \%$ & $\mathrm{CPK}$ & $69 \mathrm{IU} / 1$ \\
\hline BASO & $0.5 \%$ & Aldolase & $2.2 \mathrm{MU} / \mathrm{ml}$ \\
\hline NEUT & $46.6 \%$ & $\mathrm{LDH}$ & $454 \mathrm{IU} / \mathrm{l}$ \\
\hline LYMP & $40.0 \%$ & $\mathrm{TC}$ & $191 \mathrm{mg} / \mathrm{dl}$ \\
\hline \multirow[t]{2}{*}{ MONO } & $6.3 \%$ & AMY & $110 \mathrm{U} / 1$ \\
\hline & & BUN & $13 \mathrm{mg} / \mathrm{dl}$ \\
\hline \multirow[t]{5}{*}{ ESR } & $21 \mathrm{~mm} / \mathrm{h}$ & $\mathrm{Cr}$ & $0.8 \mathrm{mg} / \mathrm{dl}$ \\
\hline & & UA & $6.2 \mathrm{mg} / \mathrm{dl}$ \\
\hline & & $\mathrm{Na}$ & $142 \mathrm{mEq} / \mathrm{I}$ \\
\hline & & $\mathrm{K}$ & $4.2 \mathrm{mEq} / 1$ \\
\hline & & $\mathrm{Cl}$ & $105 \mathrm{mEq} / 1$ \\
\hline
\end{tabular}

$(181 \mathrm{mg} / \mathrm{dl})$. Immunological investigation of peripheral blood revealed a decrease in B lymphocytes, but the OKT4/OKT8 ratio remained normal (1.27) and lymphocyte blastic transformation by each type of mitogen was within the normal range. A tuberculin test produced a negative result. A thyroid function test revealed a normal lower limit of free T4 $(0.93 \mathrm{pg} / \mathrm{ml})$ and a slightly elevated TSH value $(7.9 \mu \mathrm{U} / \mathrm{ml})$. A TRH loading test exhibited a delayed response. Scintigraphy of the thyroid gland using ${ }^{99} \mathrm{TcO}^{-}$showed normal uptake $(1.6 \%$ in 30 minutes). An oral glucose tolerance test (OGTT) exhibited impaired glucose tolerance (IGT). A gum test for salivary secretion and sialography gave negative results. However, Schirmer's test was positive $(<10 \mathrm{~mm})$ and a rose bengal staining test was strongly positive.
Table 2. Laboratory Findings on Admission (2)

\begin{tabular}{|c|c|c|c|c|c|}
\hline \multicolumn{2}{|l|}{ Immunology } & \multicolumn{4}{|c|}{ HLA } \\
\hline CRP & $(-)$ & \multicolumn{4}{|c|}{$\mathrm{A} 24, \mathrm{~A} 31, \mathrm{BW} 54, \mathrm{BW} 60$} \\
\hline RA & $(-)$ & \multicolumn{4}{|c|}{ CW1, CW3, DR4, DR8 } \\
\hline LE test & $(-)$ & \multicolumn{4}{|c|}{ DRw52, DRw53, DQw1, } \\
\hline Antinuclear antibody & $(+)$ & \multicolumn{4}{|c|}{ DQw4 } \\
\hline \multicolumn{2}{|c|}{ centromere pattern } & \multicolumn{4}{|c|}{ Tyroid function } \\
\hline AntiENA antibody & $(-)$ & \multicolumn{2}{|c|}{ free $\mathrm{T} 4$} & \multicolumn{2}{|c|}{$0.93 \mathrm{pg} / \mathrm{ml}$} \\
\hline AntiScl-70 antibody & $(-)$ & \multirow{2}{*}{\multicolumn{4}{|c|}{$\begin{array}{c}\text { TSH } \\
\text { TRH test }\end{array}$}} \\
\hline AntiRNP antibody & $(-)$ & & & & \\
\hline AntiSS-A antibody & $(-)$ & \multicolumn{2}{|c|}{ Time $(\min )$} & \multicolumn{2}{|c|}{ TSH $(\mu \mathrm{U} / 1)$} \\
\hline AntiSS-B antibody & $(-)$ & \multicolumn{2}{|c|}{0} & & 8.3 \\
\hline AntiDNA antibody & $(-)$ & \multicolumn{2}{|r|}{15} & & 47.1 \\
\hline Antithyroglobulin antibody & $(+)$ & \multicolumn{2}{|r|}{30} & & 62.0 \\
\hline & $<1,600$ & \multirow{2}{*}{\multicolumn{2}{|c|}{60}} & & 55.6 \\
\hline \multirow[t]{2}{*}{ Antimicrosomal antibody } & $(+)$ & & & & \\
\hline & $<1,600$ & \multicolumn{4}{|c|}{$75 \mathrm{~g}$ OGTT } \\
\hline Antimitochondrial antibody & $\begin{array}{r}(+) \\
\times 160\end{array}$ & \multicolumn{3}{|c|}{$\begin{array}{ll}\text { Time } & \text { PG } \\
(\mathrm{min}) & (\mathrm{mg} / \mathrm{dl})\end{array}$} & $\begin{array}{l}\text { IRI } \\
(\mu \mathrm{U} / \mathrm{ml})\end{array}$ \\
\hline \multicolumn{2}{|c|}{ Anti-smooth muscle antibody $(+)$} & \multicolumn{3}{|c|}{$0 \quad 98$} & 1 \\
\hline \multirow{2}{*}{ Anticentromare antibodv } & $\times 320$ & \multicolumn{3}{|c|}{152} & 31 \\
\hline & $(+)$ & 60 & 17 & & 28 \\
\hline & $\times 640$ & 120 & 15 & & 40 \\
\hline Immune complex & $5 \mathrm{mg} / \mathrm{dl}$ & Liver fun & ction & & \\
\hline $\mathrm{CH} 50$ & $2.9 \mathrm{U} / \mathrm{l}$ & ICG $(1$ & & & $7.5 \%$ \\
\hline $\operatorname{IgG}$ & $0 \mathrm{mg} / \mathrm{dl}$ & & & & \\
\hline $\operatorname{Ig} A$ & $9 \mathrm{mg} / \mathrm{dl}$ & Gum test & & $10^{\prime}$ & $14 \mathrm{ml}$ \\
\hline $\operatorname{IgM}$ & $1 \mathrm{mg} / \mathrm{dl}$ & Shirmer's & test & $\begin{array}{l}\text { rt. } \\
\text { lt. }\end{array}$ & $\begin{array}{r}4 \mathrm{ml} \\
1.5 \mathrm{ml}\end{array}$ \\
\hline Tecll & $89 \%$ & & & & \\
\hline Bcell & $2 \%$ & & & & \\
\hline OKT4 & $38.8 \%$ & & & & \\
\hline OKT8 & $30.5 \%$ & & & & \\
\hline OKT4/OKT8 & 1.27 & & & & \\
\hline Lymphoblastgenesis & (S.I.*) & & & & \\
\hline PHA & 321 & & & & \\
\hline Con $\mathrm{A}$ & 221 & & & & \\
\hline PWM & 50 & & & & \\
\hline
\end{tabular}

* Stimulation Index

The patient had elevated biliary tract enzymes and tested positive for antimitochondrial antibodies, suggesting the existence of PBC. Consequently, we conducted a liver biopsy using a laparoscope. Laparoscopic findings showed smooth irregularities on the liver surface, but no tumescence. Histological findings (Fig. 2) revealed infiltration of lymphocytes and plasma cells to Glisson's capsule, extensive reduction of the bile duct, chromatic agglutination in the epithelium of the residual bile duct and partial disappearance of the epithelium. These findings were compatible with those of stage I CNSDC using Scheuer's classification. As the presence of diffuse goiter with reduced thyroid function and the serological tests suggested Hashimoto's thyroiditis, we performed an open biopsy. As shown in Fig. 3, the pathological findings were chronic inflammatory cell infiltration accompanying the lymphoid follicles, indicating classic chronic thyroiditis. A skin biopsy from the finger showed 


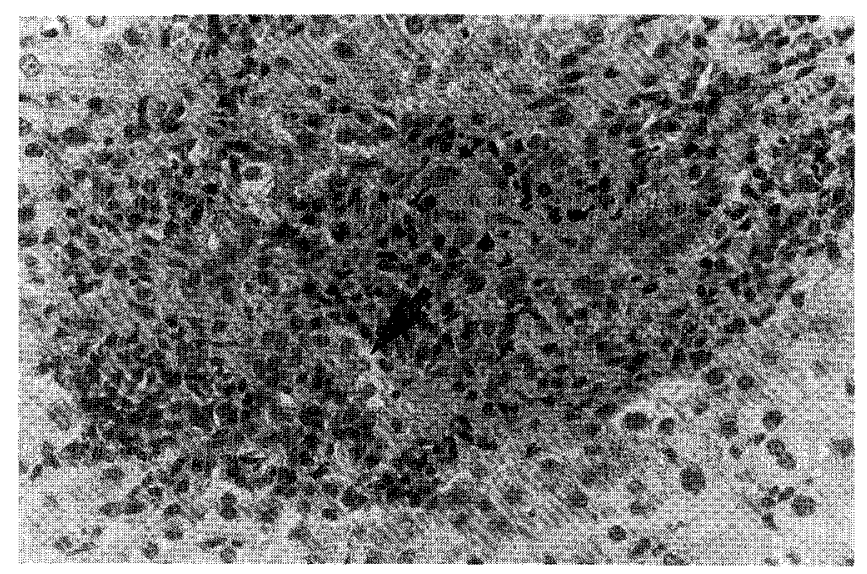

Fig. 2. Liver biopsy specimen showing lymphocyte and plasma cell infiltration to Glisson's capsule, and degeneration and partial disappearance of the epithelial cells of the bile duct (arrow). (HE stain $\times 200$ ).

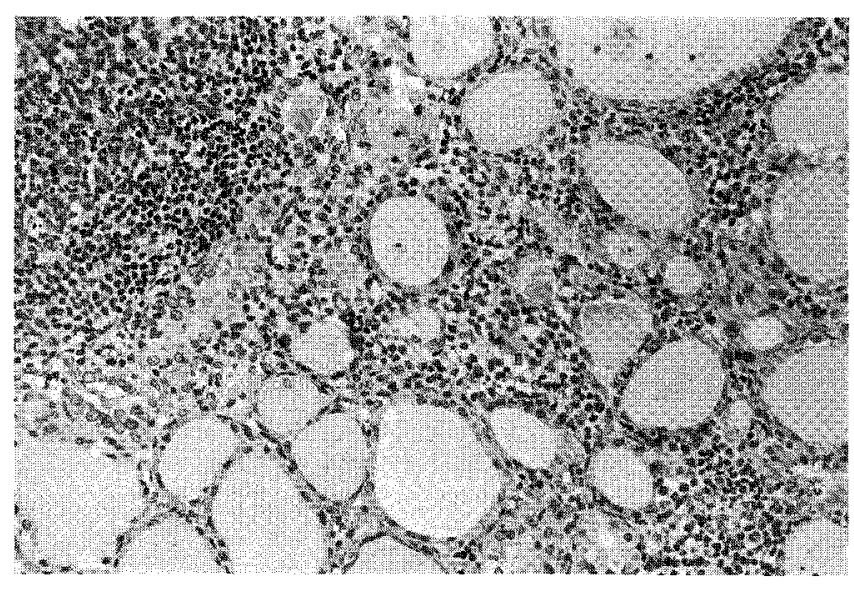

Fig. 3. Histology of the thyroid gland. Mononuclear cell infiltration with lymphoid follicles (HE stain $\times 100$ ).

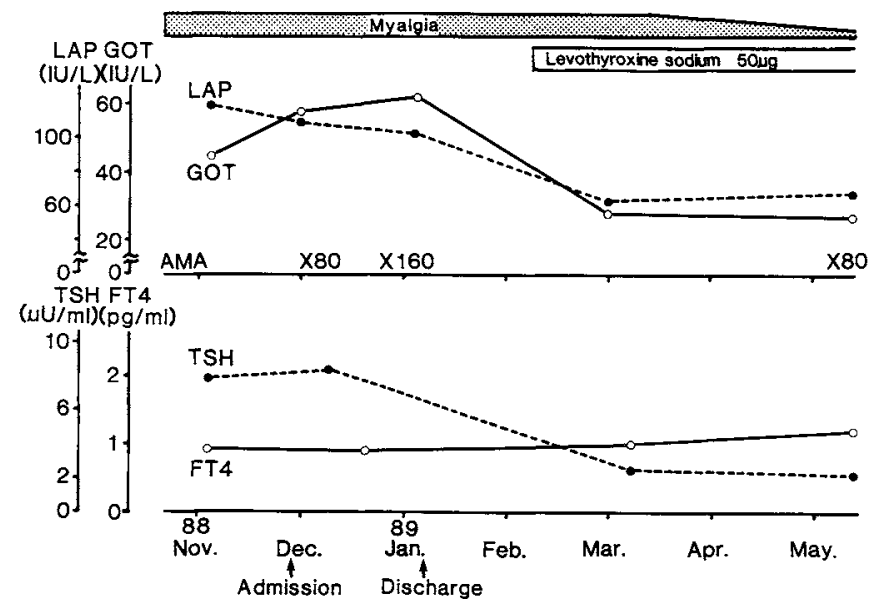

Fig. 4. Clinical course. Administration of levothyroxine $(50 \mu \mathrm{g} /$ day) improved subjective symptoms as well as GOT and biliary tract enzymes in association with normalization of thyroid function. an increase in collagen fiber, but there were no atrophic findings of the appendages.

Subjective symptoms, particularly myalgia, continued after admission despite the administration of antiinflammatory drugs. Beginning on February 8, levothyroxine was given at a dosage of $50 \mu \mathrm{g} / \mathrm{day}$. The clinical course of the patient is shown in Fig. 4. With the amelioration of thyroid function, GOT and biliary tract enzymes were also normalized, and the subjective symptoms improved. However, no change was found in the antimitochondrial antibody titer.

\section{Discussion}

The present patient showed an elevation of biliary tract enzymes, a high titer of antimitochondrial antibodies and the histological characteristics of CNSDC on liver biopsy, although jaundice and dermal pruritis did not occur. Hence, she was diagnosed as having asymptomatic PBC. In addition, a diffuse, elastic hard goiter that was diagnosèd as Hashimoto's thyroiditis because of its histology was detected through palpation. The patient also suffered from Raynaud's phenomenon and sclerodactylia, leading to the diagnosis of type I scleroderma according to Barnett's classification. Furthermore, the results of both the rose bengal staining and Schirmer's tests were positive, and keratoconjunctivitis of unknown etiology was present in this patient, thus meeting the criteria for Sjs, although no characteristic findings were observed on sialography.

Sasaki et al (1) investigated 180 cases of PBC and reported that complications of PBC were most frequent in those with Sjs (55 cases), less frequent in those with Hashimoto's thyroiditis (9 cases) and far less frequent in those with scleroderma ( 2 cases). However, the association of these four diseases is considered to be very rare (2).

It is noteworthy that the present patient showed positive results for several autoantibody tests, including antimitochondrial antibodies which are characteristic of $\mathrm{PBC}$, and anticentromere antibody which is characteristic of the CREST syndrome. Recent reports have demonstrated the presence of antimitochondrial antibodies in progressive systemic sclerosis (PSS) and anticentromere antibody in PBC (3-5), suggesting a relationship between the two disorders. The CREST syndrome is currently thought to be a limited form of PSS and the presence of anticentromere antibody appears to be a marker for a favorable prognosis in patients with PSS (6). The association between PBC and typical PSS is uncommon (7), but there have been a number of reported cases of PBC associated with mild PSS and sclerodactylia, as in our patient $(8,9)$. The liver is closely related to the thyroid gland, since it metabolizes and stores thyroid hormone. Chronic liver disease has long been implicated as a complication of Hashimoto's thyroiditis, and Fukase 
and Ito (10) proposed the term "liver-thyroiditis syndrome" to describe the condition. It is conceivable that the coexistence of PBC and Hashimoto's thyroiditis in our patient is compatible with this concept. The high incidence of PBC with Sjs was partly explained by the presence of a common antigen in the epithelium of the bile and salivary gland ducts (11).

Tanaka et al (2) reported a case of PBC associated with PSS, Hashimoto's thyroiditis, and Sjs. Compared with their case, the present patient showed a high titer of autoantibodies but had less severe clinical symptoms. The reason for this is not clear, but it has been reported that the titer and variation of antimitochondrial antibodies are not related to the severity of $\mathrm{PBC}$. The coexistence in both patients of four different autoimmune diseases may not have occurred by chance, but may be attributed to the autoimmune reaction elicited by the recognition of common antigens in each organ. Common antigenicities may exist in the epithelium of the bile duct and the thyroid gland follicle or salivary gland. The expression of class II MHC antigens on epithelial cell surfaces of the bile duct that normally do not express them can be induced by certain agents (eg. cytokines). Recognizing these molecules, CD4 $\mathrm{T}$ lymphocytes induce cytotoxic $\mathrm{T}$ lymphocytes and produce lymphokines, which damage cells with common antigens. There have been reports of abnormal cellular immunity such as elevation of the OKT4/OKT8 ratio and reduction in each mitogen-stimulated lymphocyte blastic transformation in biliary cirrhosis $(12,13)$. In the present patient, all of these indices were normal.

It is interesting that the administration of thyroid drugs resulted in not only an improvement in thyroid function, but also normalization of GOT and biliary tract enzymes and further amelioration of subjective symptoms. Miki et al (14) reported that replacement therapy for reduced thyroid function in Hashimoto's thyroiditis with $\mathrm{PBC}$ led to an improvement in abnormal findings related to $\mathrm{PBC}$ in addition to improvement in thyroid function. Although the mechanisms responsible for this improvement are unclear, a recent experimental study revealed that thyroid function may influence bile flow. Layden and Boyer (15) reported that the administration of L-thyroxine to hypothyroid animals restored bile acid-independent canalicular secretion that was associated with an increase in the activity of liver plasma membrane enzymes such as $\mathrm{Na}^{+}, \mathrm{K}^{+}$-ATPase. Keeffe et al (16) also reported that bile acid-independent flow was increased by thyroid hormone in rats. Improvement in bile flow may result in an improvement in liver cell dysfunction due to bile stagnancy. These experimental findings may hold true for the present patient. However, the possibility that subsequent thyroid hormone-induced improvement in systemic metabolism exerted a favorable effect on the immune system that is linked to liver function cannot be excluded. PBC has been recognized as a progressive disease with a poor prognosis, but the recent advances in diagnostic technology make it possible to diagnose patients at an asymptomatic stage. Patients with PBC follow one of two clinical courses; one form rapidly progresses through symptomatic $\mathrm{PBC}$ to liver cirrhosis, and the other remains asymptomatic for many years. The mechanisms underlying the differences between the clinical courses are not known. However, the findings in the present patient and the case reported by Miki et al (14) indicate the possible inhibitory effect of thyroid drugs on the progression of PBC.

\section{References}

1) Sasaki $H$, Inoue $K$, Higuchi $K$, et al. Primary biliary cirrhosis in Japan: national survey by the Subcommittee on Autoimmune Hepatitis. Gasteroenterol Jpn 20: 476, 1985.

2) Tanaka $E$, Imai $T$, Nosawa $K$, et al. A case of primary biliary cirrhosis complicated with progressive systemic sclerosis, Sjögren's syndrome and Hashimoto's thyroiditis. Kanzo 22: 1473, 1981.

3) Alderuccio F, Toh BH, Barnett AJ, Pedersen JS. Identification and characterization of mitochondria autoantigens in progressive systemic sclerosis: identity with the 72,000 Dalton autoantigen in primary biliary cirrhosis. J Immunol 137: 1855, 1986.

4) Gupta RC, Seibold JR, Krishnan MR, Steigerwald JC. Precipitating autoantibodies to mitochondrial proteins in progressive systemic sclerosis. Clin Exp Immunol 58: 68, 1984.

5) Bernstein RM, Callender ME, Neuberger JM, Hughes GRV, Williams R. Anticentromere antibody in primary biliary cirrhosis. Ann Rhuem Dis 41: 612, 1982.

6) Kondo H, Uchida K, Kashizaki S. Clinical significance of immunological abnormality in PSS. Clin Immunol 16: 197, 1984.

7) Sherlock S, Scheuer PJ. The presentation and diagnosis of 100 patients with primary biliary cirrhosis. N Engl J Med 289: 674, 1973.

8) Clarke AK, Galbraith RM, Hamilton EBD, Williams R. Rheumatic disorders in primary biliary cirrhosis. Ann Rheum Dis 37: 42, 1978.

9) Gupta RC, Dickson ER, Mcduffie FC, Baggenstoss AH. Immune complexes in primary biliary cirrhosis: higher prevalence of circulating immune complexes in patients with associated autoimmune features. Am J Med 73: 192, 1982.

10) Fukase S, Ito K. Liver-thyroiditis syndrome. Jpn Med J 2486: 3, 1968.

11) Mcfarlane IG, Wojcicka BM, Tsantoulas DC, et al. Cellular immune responses to salivary antigens in autoimmune liver disease with sicca syndrome. Clin Exp Immunol 25: 389, 1976.

12) Ishihara $\mathrm{K}$, Asakura $\mathrm{H}$. Abnormalities of immune regulation in primary biliary cirrhosis. Med Immunol 17: 683, 1989.

13) Yamashiki $M$, Honda $K$, Ota $H$, Arakawa $K$, Ichida F. Immunoregulatory disorders in primary biliary cirrhosis. Med Immunol 12: 643, 1986

14) Miki T, Sakane T, Takada S, et al. Development of asymptomatic primary biliary cirrhosis in patients with Hashimoto's thyroiditis and improvement of the liver disease by treatment of thyroiditis. J Jpn Soc Intern Med 77: 524, 1988.

15) Layden TJ, Boyer JL. The effect of thyroid hormone on bile salt-independent bile flow and $\mathrm{Na}^{+}, \mathrm{K}^{+}$-ATPase activity in liver plasma membrane enriched in the bile canaliculi. J Clin Invest 57: 1009, 1976.

16) Keeffe EB, Scharschmidt BF, Blankenship NM, Ockner RK. Studies of relationships among bile flow, liver plasma membrane NaK-ATPase, and membrane viscosity in the rat. J Clin Invest 64: $1590,1979$. 